\title{
Web-Based Teacher Performance Assessment Information System Using Simple Additive Weighting (SAW) Method
}

\author{
Abdul Muhyiddin ${ }^{1}$ \\ Information System \\ Faculty of Engineering And Computer Science \\ University Buana Perjuangan \\ Karawang, Indonesia \\ si17.abdulmuhyiddin@mhs.ubpkarawang.ac.id
}

\author{
Saepul Aripiyanto ${ }^{2}$ \\ Information System \\ Faculty of Engineering And Computer Science \\ University Buana Perjuangan \\ Karawang, Indonesia \\ saepularipiyanto@ubpkarawang.ac.id
}

\author{
Baenil Huda ${ }^{3}$ \\ Sistem Informasi \\ Faculty of Engineering And Computer Science \\ University Buana Perjuangan \\ Karawang, Indonesia \\ Baenil88@ubpkarawang.ac.id
}

\begin{abstract}
SMP IT Nurul Huda Batujaya is one of the educational institutions for school students in Batujaya District, Karawang Regency. The research objective is to develop teacher performance appraisal. The research method using qualitative methods aims to describe the data analysis in a narrative manner. Methods of data collection by observation, interviews, and literature study. Teacher performance assessment is still done manually by using Microsoft Excel and Microsoft Word. Other problems are needed, namely, the high cost of printing documents from each teacher, the documents submitted to the administration department are often damaged and confused, the assessment team must carry a lot of documents during the assessment, and errors during the assessment recapitulation. This can have an impact on delays in the teacher performance assessment process. The system development method uses the waterfall, Hypertext Preprocessor (PHP) programming language, MySQL, and the Simple Additive Weighting (SAW) method. The results achieved in this study can create and design a teacher performance appraisal information system to help the assessment process quickly and correctly to reduce the occurrence of errors.
\end{abstract}

Keywords: Information System, PHP, Mysql, Teacher Performance Assessment, SAW

Abstrak - SMP IT Nurul Huda Batujaya merupakan salah satu lembaga pendidikan bagi siswa sekolah di Kecamatan Batujaya, Kabupaten Karawang. Tujuan penelitian adalah untuk mengembangkan penilaian kinerja guru. Metode penelitian yang menggunakan metode kualitatif bertujuan untuk mendeskripsikan analisis data secara naratif. Metode pengumpulan data dengan observasi, wawancara, dan studi kepustakaan. Penilaian kinerja guru masih dilakukan secara manual dengan menggunakan Microsoft Excel dan Microsoft Word. Masalah lain yang dibutuhkan yaitu, mahalnya biaya pencetakan dokumen dari setiap guru, dokumen yang diserahkan ke bagian tata usaha sering rusak dan membingungkan, tim penilai harus membawa banyak dokumen saat penilaian, dan kesalahan saat rekapitulasi penilaian. Hal ini dapat berdampak pada keterlambatan proses penilaian kinerja guru. Metode pengembangan sistem menggunakan metode waterfall, bahasa pemrograman Hypertext Preprocessor (PHP), MySQL, dan metode Simple Additive Weighting (SAW). Hasil yang dicapai dalam penelitian ini dapat membuat dan merancang sistem informasi penilaian kinerja guru untuk membantu proses penilaian secara cepat dan benar untuk mengurangi terjadinya kesalahan.

Kata kunci: Sistem Informasi, PHP, Mysql, Penilaian Kinerja Guru, SAW

\section{PRELIMINARY}

The task of a teacher is so important that many experts state that in schools there will be no change or improvement in quality without changes and improvements in educators. The teacher is a figure who can shape the soul and character of students. Teachers can shape the character of students to become valuable for the religion of the nation and state, teachers play a role in conveying the information they have to students from teachers, students are educated to read, write and count and it is from educators that students get new information and foster the character of educators as people. the second parent in the school who acts as a teacher as a companion who can guide a motivator and supporter [1]. Furthermore, to ensure educators in providing teaching at SMP IT Nurul Huda Batujaya, they direct teacher performance assessments. Teacher performance appraisal is very valuable to spur the enthusiasm of teachers to continue to improve their quality. In Indonesia, teachers generally refer to competent schools with the main task of teaching, educating, directing, training, assessing, guiding, and assessing students. In general, teachers are educators, teachers in schools.

A method is a way that is identified with a way of functioning in achieving the goals that users need so that they can understand the goals that can solve the problem. Smp IT Nurul Huda Batujaya as a private school, also carries out teacher performance assessments, as a guarantee of the quality of educators honing their teaching skills. In the implementation of teacher performance assessment towards the end of the lesson. The implementation of teacher performance assessment is assisted by taking the 
teacher assessment sheet that has been given by the school. In one class students are divided into four groups and in one day four teachers are teaching so that one group assesses one teacher. Until now, teacher performance assessment sheets are still carried out routinely, by filling out the teacher's performance on a piece of paper and then collecting it. Using this system will take a long time because it must be recapitulated. The recapitulation process takes a long time because it has to be scanned one by one by the administration, then the filling is only done by certain students who happen to take part in learning activities and who want to take the provided polymers and there are no categories of assessment results.

Given these shortcomings, teacher performance assessment requires the development of information technology to facilitate teacher performance assessment. One of them uses a web-based teacher performance appraisal information system using the simple additive weighting (SAW) method.

The research method used by the author is simple additive weighting (SAW). This method was chosen because it determines the weight value for each attribute, with a ranking process that will choose the best alternative, which is the choice of teachers who have teacher performance assessments based on specified criteria. With the simple additive weighting (SAW) method, it will be more precise depending on the value of the criteria and weights that have been determined [2].

In teacher performance assessment research, there are indicators of teacher performance assessment, especially pedagogic, personality, social, and professional as assessment criteria, each of which has its assessment importance. The information obtained in determining teacher performance assessments is obtained through primary data and secondary data depending on the observation and monitoring of teacher activities, with this system can help SMP IT NURUL HUDA Batujaya in assessing teacher performance quickly and easily.

\section{METHODS}

A. System

According to Jogiyanto in Kartikasari (2016), the system is a network of interconnected procedures, gathered together to carry out an activity or to complete a certain goal. So, the system is a collection of interconnected network components, to achieve a predetermined goal together [3].

B. Information

According to Pratama in Prabowo and Syani (2016) information is the result of processing data from one or various sources which are then processed, thus providing value, meaning, and benefits [4].

According to Jogiyanto in Kartikasari (2016) information is data that is processed into a form that is more useful and more meaningful for those who receive it. Information usually has a source, namely data.

C. Information System

According to Ladjamudin in Prabowo and Syani (2016) information systems based on the definition of systems and information described above, it can be stated that the information system is a combination of four main parts [5]. The four main sections include hardware software, infrastructure, and trained human resources.

\section{Assessment}

Performance is an expression of the word performance in English which has three meanings, namely: achievement, performance, and task execution. Ruky, in Supardi (2016, p. 45). Meanwhile, in the general Indonesian dictionary (2016, p. 598) performance has three meanings, namely: "way, ability, and attitude or behavior"[6]. In addition, Supardi (2016, p. 46) suggests three other meanings of performance, namely: "work results, abilities, and achievements or encouragement to carry out a job". Based on this opinion, it can be concluded that performance is an achievement/work produced by attitudes/behaviors based on ability and carrying out their duties. The performance will be an achievement if it shows activity in carrying out the tasks that have been charged. The definition of performance is often identified with work performance because there are similarities with work performance [7]. Work performance itself is the result of a person's work in a certain period. Work performance can be meaningful in its entirety if it is distinguished between standards, targets, and criteria that have been previously agreed upon. (Suprihantoro in Supardi, 2016, p. 45).

\section{E. Teacher Performance Assessment}

Teacher performance assessment is an assessment designed to identify the ability of teachers in carrying out their duties through measuring the mastery of competencies shown in their performance" (Prisma, 2018 p. 355) to find out how much a person's performance is needed a tool or activity to measure a person's performance in a work unit or organization[8]. A tool or activity that can be done to measure a person's performance is a teacher performance appraisal tool, designed by taking into account the teacher's performance indicators "(Nurdiansyah, 2018 p. 33). Teacher performance assessment is carried out to fully describe how the teacher's performance is [9]. Next Priansa $(2018$, p. 393) that "the implementation of teacher performance assessment involves various parties, starting from the central level, up to the principal level.

F. Web

According to Sidik, the website was originally an information presentation service that uses the concept of hyperlinks that make it easier for surfers (a term for computer users who browse information on the internet) to get information simply by clicking on a link in the form of text or images that will be displayed in more detail (Arizona, 2010). 2017)[10].

\section{G. Class Diagram}

The class diagram is the structure of the program system on the types that are formed and is the flow of the database on a system [11]. Class diagrams describe the 
structure of the system in terms of defining the classes that will be created to build the system. The class diagram is a diagram that is used as a modeling of the classes in the system that are interconnected and use important elements.

\section{H. Use Case Diagram}

Use case diagram is a model for the behavior or behavior of the system to be made. A use case describes an interaction between one or more actors with the system to be created. Use cases are used to find out what functions are in a system and who has the right to use those functions [12].

\section{Activity Diagram}

Activity diagram is a diagram to provide modeling of the dynamic aspects of a type system from which the user consists of two different types, each user has different access rights. Activity diagrams describe the workflow or workflow of a system. Noteworthy is that the activity diagram depicts system activities, not actor activities.

\section{J. Sequence Diagram}

The sequence diagram illustrates the behavior of the object in the use case by describing the lifetime of the object and the massage sent between objects [9]. Therefore, to describe a sequence diagram, it is necessary to know the objects involved in a use case and their methods. The number of sequence diagrams depends on the number of use cases defined [13].

K. System Development Life Cycle

The stages in system development using the System Development Life Cycle (SDLC) which is based on the model and process used by the developer to create a software system and describe the process, namely to obtain solutions to existing problems [14]. According to Sukamanto and Shalahudin (2016: 28), the waterfall method is a linear sequential model or the classical life flow of the waterfall model providing a sequential software life flow or starting from analysis, design, implementation, testing, and maintenance which ends in ongoing support for completion. software. The following is a picture of a waterfall model according to Sukamto and Saladin.

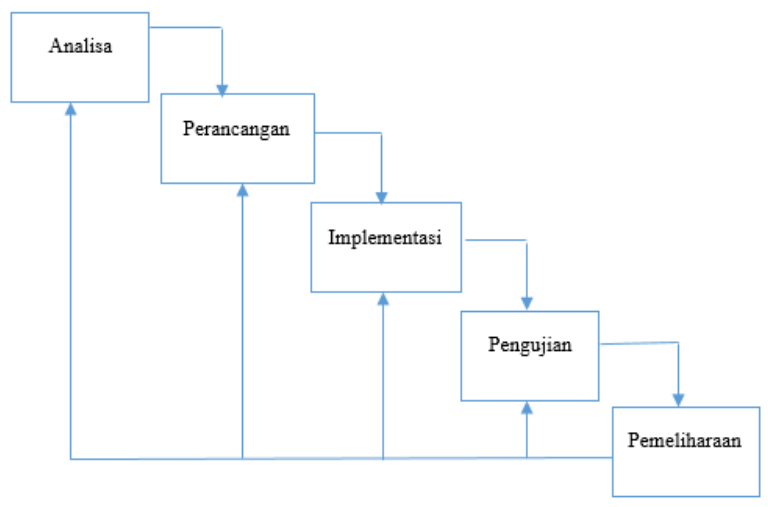

Figure 1 Waterfall Model (Waterfalls, 2016)

1. Needs analysis

At this stage, the development must know all the information about the software requirements such as the usability desired by the user and the limitations of the software. This information is usually obtained from interviews, surveys, or discussions. After that, the information is analyzed to get complete data regarding user needs.

2. Design

Aims to provide a complete picture of what must be done and how the desired system will look. So that it helps the hardware and system needs that will be made as a whole.

3. Implementation

In this stage, a deeper examination will be carried out on the module that has been made, whether it has fulfilled the desired function or not.

4. Test

Which aims to find out whether it is according to the desired design and whether there are still errors or not.

5. Maintenance

The final stage of the ready-made waterfall software development method will be run or operated by the user, besides that maintenance is carried out which includes repairs to the system.

\section{B. Black Box}

Testing the black box method is testing the prototype of the function of the hardware information system [15]. According to Lukman states that: black box testing is a stage that focuses on the functional statement of the software. This test case aims to show the software functions on how to operate. Has data entry been running properly and whether the stored information can be kept up-to-date (Hidayat, 2017)

\section{RESULTS AND DISCUSSION}

In developing a web-based teacher performance appraisal information system using the simple additive weighting (SAW) method and then analyzing the application of simple additive weighting (SAW), and designed with PHP and MySQL, using the Unified Modeling Language (UML) which includes class diagrams, Use Case Diagrams, activity diagrams, sequence diagrams.

\section{A. Analysis of the Application of Simple Additive Weighting (SAW)}

To determine the teacher's performance assessment by what is desired, the author uses the Simple Additive Weighting (SAW) method. This method is very appropriate to be implemented in the case of teacher performance assessment at SMP IT NURUL HUDA Batujaya.

Calculation of data manually, to get a weighted value in a way, each criterion has competence and competence has indicators or questions, obtained through observation and monitoring of teacher activities, the number of questions will be calculated to be used as a weight value (w) according to what has been determined by the head school. 
Table.1. Weight

Students make an assessment of the teacher based on the category of assessment factors as follows.

Performance appraisal category

1. Not Fulfilled $=0$

2. $\quad$ Fulfilled $=1$

3. Highly Fulfilled $=2$

How many students choose a category when assessing teachers, the results obtained will be added up. Then the results that students give value to the teacher are as follows.

Table.2 Criteria

\begin{tabular}{|c|c|c|c|c|}
\hline \multirow{2}{*}{ Alternative } & \multicolumn{4}{|c|}{ Criteria } \\
\cline { 2 - 5 } & Pedagogic & Personality & Social & professional \\
\hline Teacher 1 & 92 & 34 & 12 & 18 \\
\hline Teacher 2 & 50 & 16 & 3 & 9 \\
\hline Teacher 3 & 47 & 17 & 7 & 9 \\
\hline Teacher 4 & 54 & 17 & 6 & 14 \\
\hline Teacher 5 & 46 & 17 & 6 & 9 \\
\hline
\end{tabular}

The value that has been obtained will be entered into the calculation of the Simple Additive Weighting (SAW) formula [16].

$\left\{\begin{array}{l}\frac{x_{i j}}{\operatorname{Max} x_{i j}} \\ \frac{\operatorname{Min}_{i j}}{x_{i j}} \text { jika } j \text { adalah atribut keuntungan (benefit) }\end{array}\right.$

\section{Pedagogic}

$\mathrm{R} 11=\frac{92}{\operatorname{Max}(92504754 \quad 46)}=\frac{92}{92}=1$

$\mathrm{R} 12=\frac{50}{\operatorname{Max}(9250475446)}=\frac{50}{92}=0.543$

$\mathrm{R} 13=\frac{47}{\operatorname{Max}(9250475446)}=\frac{47}{92}=0.511$

$\mathrm{R} 14=\frac{54}{\operatorname{Max}(9250475446)}=\frac{54}{92}=0.587$

$\mathrm{R} 15=\frac{46}{\operatorname{Max}(9250475446)}=\frac{46}{92}=0.5$

\section{Personality}

$\mathrm{R} 11=\frac{34}{\operatorname{Max}(3416171717)}=\frac{34}{34}=1$

$\mathrm{R} 12=\frac{16}{\operatorname{Max}(3416171717)}=\frac{16}{34}=0.471$

$\mathrm{R} 13=\frac{17}{\operatorname{Max}(3416171717)}=\frac{17}{34}=0.5$

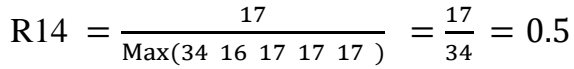

\begin{tabular}{|c|c|c|}
\hline No & Criteria & Weight(W) \\
\hline 1 & Pedagogic & 46 \\
\hline 2 & Personality & 18 \\
\hline 3 & Social & 6 \\
\hline 4 & Professional & 9 \\
\hline
\end{tabular}

$\mathrm{R} 15=\frac{17}{\operatorname{Max}\left(\begin{array}{lll}34 & 16171717\end{array}\right)}=\frac{17}{34}=0.5$

Social

$\mathrm{R} 11=\frac{12}{\operatorname{Max}(126766)}=\frac{12}{12}=1$

$\mathrm{R} 12=\frac{6}{\operatorname{Max}(126766)}=\frac{6}{12}=0.5$

$\mathrm{R} 13=\frac{7}{\operatorname{Max}(126766)}=\frac{7}{12}=0.583$

$\mathrm{R} 14=\frac{6}{\operatorname{Max}(126766)}=\frac{6}{12}=0.5$

$\mathrm{R} 15=\frac{6}{\operatorname{Max}(126766)}=\frac{6}{12}=0.5$

\section{Professional}

$\mathrm{R} 11=\frac{18}{\operatorname{Max}(1899149)}=\frac{18}{18}=1$

$\mathrm{R} 12=\frac{9}{\operatorname{Max}(1899149)}=\frac{9}{18}=0.5$

$\mathrm{R} 13=\frac{9}{\operatorname{Max}(1899149)}=\frac{9}{18}=0.5$

$\mathrm{R} 14=\frac{14}{\operatorname{Max}(1899149)}=\frac{14}{18}=0.778$

$\mathrm{R} 15=\frac{9}{\operatorname{Max}(1899149)}=\frac{9}{18}=0.5$

From the results of the pedagogic, personality, social, and professional calculations above, the normalization of the $\mathrm{R}$ matrix is made as below.

$R=\left(\begin{array}{cccccc}1 & 0.543 & 0.511 & 0.587 & 0.5 \\ & 1 & 0.471 & 0.5 & 0.5 & 0.5 \\ & 1 & 0.5 & 0.583 & 0.5 & 0.5 \\ 1 & 0.5 & 0.5 & 0.778 & 0.5\end{array}\right)$

The preference value for each alternative $(\mathrm{Vi})$ is given as.

$$
V_{i}=\sum_{j=i}^{n} w_{j} r_{i j}
$$

Calculation of data manually, each indicator that already exists is given a weight (W) according to what has been determined by the principal.

$\mathrm{W}=46,18,6,9$

Doing the Ranking Process

$\mathrm{V} 1=(46)(1)+(18)(1)+(6)(1)+(9)(1)$

$=46+18+6+9$

$=79$

$\mathrm{V} 2=(46)(0.543)+(18)(0.471)+(6)(0.5)+(9)(0.5)$

$=24.978+8.478+3+4.5$

$=40.96$

$\mathrm{V} 3=(46)(0.511)+(18)(0.5)+(6)(0.583)+(9)(0.5)$

$=23.506+9+3.498+4.5$

$51 \mid$ Vol.2 No.2, July 2021 
$=40.5$

$\mathrm{V} 4=(46)(0.587)+(18)(0.5)+(6)(0.5)+(9)(0.778)$

$=27.002+9+3+7.002$

$=46$

$\mathrm{V} 5=(46)(0.5)+(18)(0.5)+(6)(0,5)+(9)(0.5)$

$=23+9+3+4.5$

$=39.5$

Table 3 Assessment Results

\begin{tabular}{|l|l|}
\hline Name & Score \\
\hline Teacher 1 & 79 \\
\hline Teacher 2 & 40.96 \\
\hline Teacher 3 & 40.5 \\
\hline Teacher 4 & 46 \\
\hline Teacher 5 & 39.5 \\
\hline
\end{tabular}

\section{B. Use Case}

Admin is in charge of filling in teacher data, filling in student data, user data, criteria data, competency data, question data, assessment data, report data.

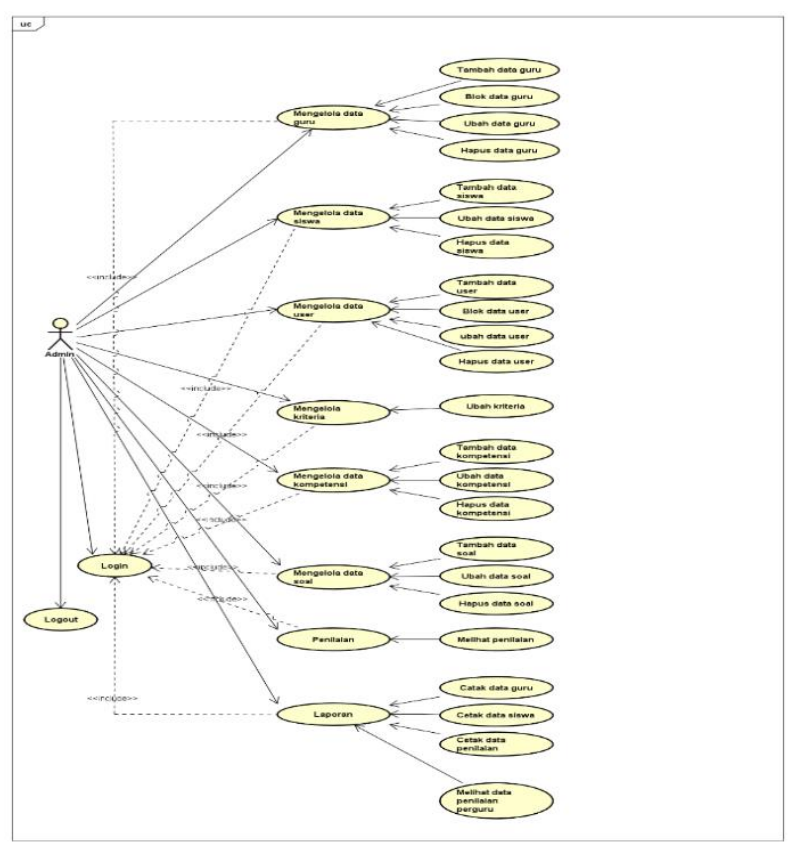

Figure 1 Use Case Diagram

\section{Activity Diagram}

The activity diagram depicts students accessing the system to the main page, then clicking the questionnaire to assess the teacher.

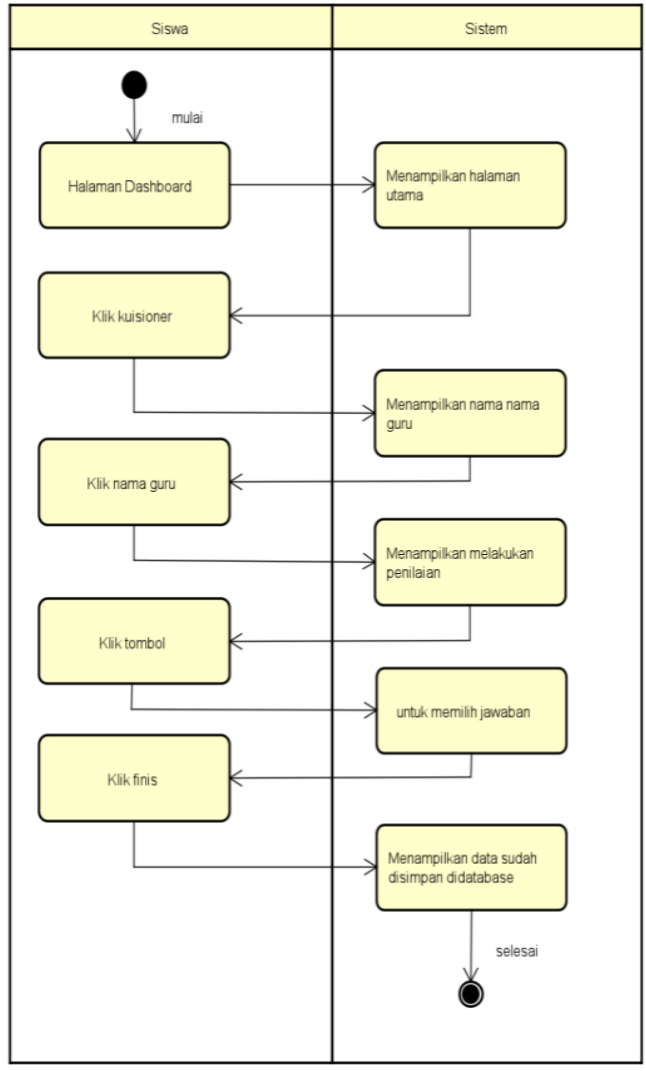

Figure 2 Student Activity Diagram

D. Sequence Diagram

Sequence diagrams describe the behavior of objects in the use case by describing the lifetime of the object and the messages sent between objects. The following is a design sequence made to design teacher performance assessments.

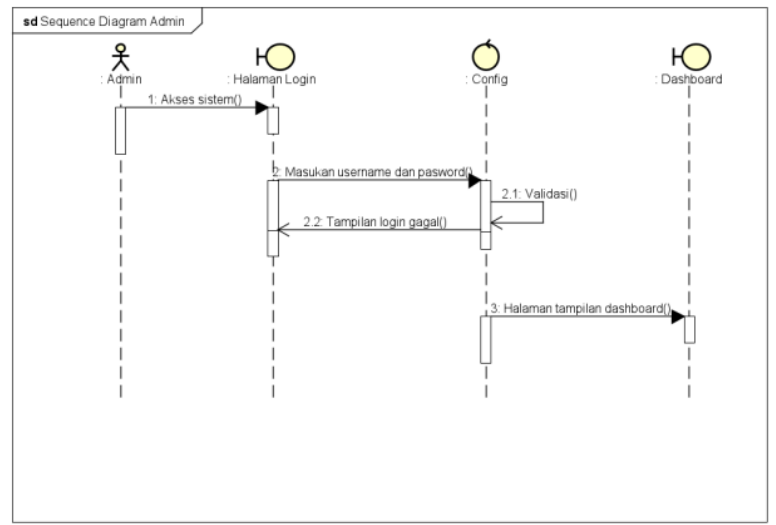

Figure 3 Admin Sequence Diagram

E. User Interface Design

The design of the user interface is made as to the delivery of information on the appearance of the application that will be made, with the design of the user interface of the secretariat give input what kind of display should be made. The following is the design of the user interface and an explanation of the function of each form of the application that will be made: 


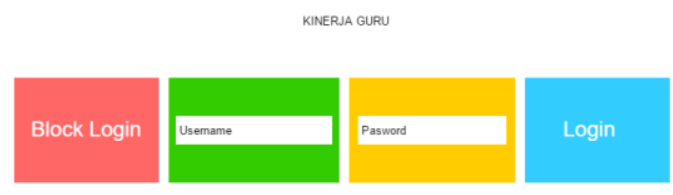

Figure 4 Login Display

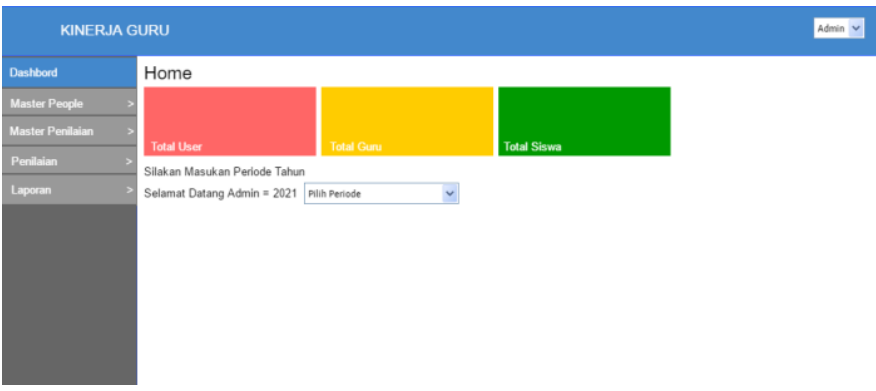

Figure 5.Admin Main Menu

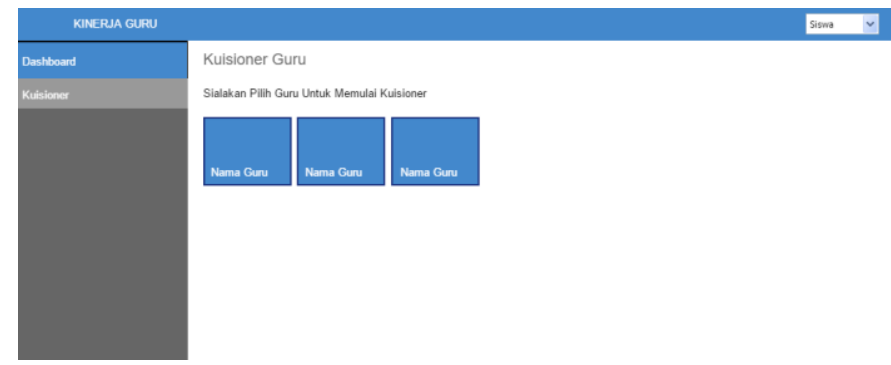

Figure 6 Student Main Menu

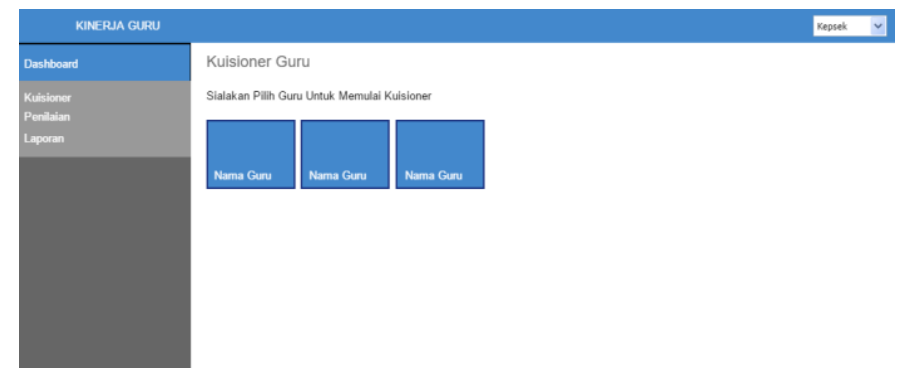

Figure 7 Teacher's Main Page

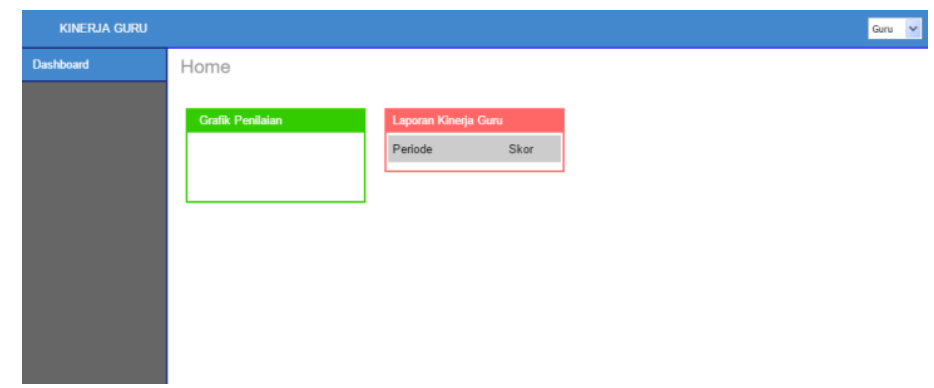

Figure 8 Teacher's Main Page

\section{CONCLUSION}

The conclusions that can be drawn from the results of research on web-based teacher performance appraisal information systems using the Simple Additive Weighting
(SAW) method at SMP IT NURUL HUDA Batujaya are as follows:

1. With this teacher performance appraisal system, it can accelerate and facilitate students, teachers, principals, and administrative staff in conducting teacher performance appraisal activities.

2. The teacher performance appraisal information system can help the teacher's ability to determine competence.

3. Simple Additive Weighting (SAW) in the assessment information system can help teacher performance, especially at SMP IT NURUL HUDA Batujaya.

\section{REFERENCES}

[1] Aneu Yulianeu Dan Aziz Abdillah (2019) Sistem Informasi Penilaian Kinerja Guru (PKG) Berbasis Web Di Sekolah Dasar Negeri 5 Tanjung Jaya Kecamatan Rajadesa Kabupaten Ciamis, JUMANTAKA Vol 03 No 01 PISSN: 2613 / ISSN: 2613-9146 journal Manajemen Dan Teknik Informatika.

[2] Anita Yusmar Dan Geovane Farel (2020) Rancang Bangun Sistem Informasi Penilaian Kinerja Guru Berbasis Web Dengan Menggunakan Framework Codeigniter 3 (Studi Kasus SMK Negeri 2 Padang Panjang) journal Vocational teknik Elektronika dan Informatika

[3] Dani Ainun Rivai Dan Bambang Eka Purnama (2014) Pembangunan Sistem Informasi Pengolahan Data Nilai Siswa Berbasis Web Pada Sekolah Menengah Kejuruan (SMK) IJNS-Indonesia journal on Networking-volume $3 \mathrm{No} 2$

[4] Lukman Hakim Dan Mustaqiem (2015) Sistem Informasi Penilaian Kinerja Guru Pada Sma Negeri 2 Sampit Berbasis Desktop.

[5]Nursahid, Berliana Kusuma Dan Bambang Eka Purnama (2015) Pembangunan Sistem Informasi Penilaian Hasil Belajar Siswa Sekolah Menengah Atas (SMA) Negeri 2 Rembang Berbasis Web, IJNSIndonesia Journal on Networking and Security-Volume 4 No 2 -ijns.org.

[6] Ramadhania Hendarti Dan Ghofar Taufik (2018) Metode Simple Additive Weighting (SAW) Dalam Penilaian Kinerja Guru SMP Bina Insani Ict Journal, Vol 5, No. 2 ISSN: 2355-3421(Print) ISSN: 25279777(Online)

[7] Riesda Ganevi Dan Bambang Eka Purnama (2014) Sistem Pendukung Keputusan Penilaian Kinerja Guru Sekolah Menengah Pertama Negeri (SMP N) 1 Pacitan journal Speed-Sentral Penelitian Engineering Dan Edukasi-volume 6 No 4-ijns.org.

[8]Siti Suprihatin (2015) Upaya Guru Dalam Meningkatkan Motivasi Belajar Siswa ISSN:2442-9449 vol 3 No.1 7382 journal Promosi \& journal pendidikan Ekonomi UM Metro.

[9] Natsir, M. 2008. Studi Efektivitas Mekanisme Transmisi 
Kebijakan Moneter di Indonesia Melalui Jalur Suku Bunga, Jalur Nilai Tukar, dan Jalur Ekspektasi Inflasi Periode 1990:2-2007:1. Disertasi. Program Pasca Sarjana Universitas Airlangga. Surabaya.

[10]Verdanasari, E. F. 2012. Pengaruh Penerapan Corporate Governance terhadap Nilai Perusahaan dengan Kualitas Laba sebagai Variabel Intervening. Skripsi. Sekolah Tinggi Ilmu Ekonomi Indonesia (STIESIA). Surabaya.

[11]Susanto, R., dan Andriana, A. D. (2016). Perbandingan Model Waterfall Dan Prototyping Untuk Pengembangan Sistem Informasi. Majalah Ilmiah UNIKOM, 14(01), 4164.

[12] Destiningrum, M., dan Adrian, Q. J. (2017). Sistem Informasi Penjadwalan Dokter Berbasis Web Dengan Menggunakan Codeigniter. Jurnal Teknoinfo, 11(2), 3037.

[13]Saepul Aripiyanto Dan Baenil Huda Sistem Pembeljaran Berbasis Web Menggunakan Framwork Codeigniter di SMK IPTEK Purwasari Karawang.

Journal of Information System and Multimedia (JoISM) https://scholar.google.co.id/scholar?hl=id\&as_sdt=0\% 2C5\&q=jurnal+Baenil+huda\&btnG=\#d=gs_qabs\&u= $\% 23 \mathrm{p} \% 3 \mathrm{DTahrXgB} 9 \mathrm{atcJ}$

[14] Bayu Priyatna, Topan Triyanto, Julifer P Manurung, Nono Heryana danArip Solehudin Sistem Preventive Maintenance Berbasis Web dengan menggunakan Algoritma Priority Scheduling pada PT. Beta Pharmacon. https://scholar.google.co.id/scholar?start=10\&q=jurnal +bayu+priyatna\&hl=id\&as_sdt=0,5\#d=gs_qabs\&u=\% 23p\%3Db5uc76ITY3AJ

[15] Triyanto, Bayu Priyatna Dan Saepul Aripiyanto Sistem Informasi Monitoring Kualitas Alat Ukur Berbasis Web Menggunkan Pengujian White Box Testing.

https://scholar.google.co.id/scholar?start=10\&q=jurnal +bayu+priyatna\&hl=id\&as_sdt=0,5\#d=gs_qabs\&u=\% 23p\%3DcfYzfcsstiwJ

[16] Topan Setiawan Dan Bayu Priyatna Implementation of Simple Additive Weighting (SAW) Method To Determine Exemplary PKH Worker (Case Study: PPKH Garut Regency). 